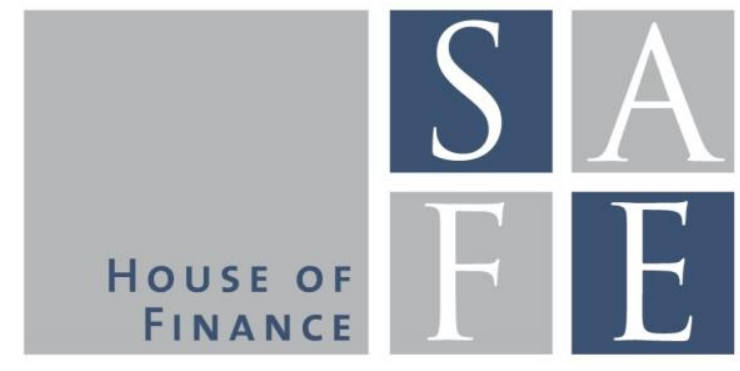

WORKING PAPER SERIES

Jens-Hinrich Binder

\title{
Banking Union and the Governance of Credit Institutions - A Legal Perspective
}

SAFE Working Paper No. 96

SAFE I Sustainable Architecture for Finance in Europe A cooperation of the Center for Financial Studies and Goethe University Frankfurt 


\title{
Banking Union and the Governance of Credit Institutions
}

\author{
A Legal Perspective
}

\author{
Jens-Hinrich Binder ${ }^{*}$
}

\begin{abstract}
The creation of the Banking Union is likely to come with substantial implications for the governance of Eurozone banks. The European Central Bank, in its capacity as supervisory authority for systemically important banks, as well as the Single Resolution Board, under the EU Regulations establishing the Single Supervisory Mechanism and the Single Resolution Mechanism, have been provided with a broad mandate and corresponding powers that allow for far-reaching interference with the relevant institutions' organisational and business decisions. Starting with an overview of the relevant powers, the present paper explores how these could - and should - be exercised against the backdrop of the fundamental policy objectives of the Banking Union. The relevant aspects directly relate to a fundamental question associated with the reallocation of the supervisory landscape, namely: Will the centralisation of supervisory powers, over time, also lead to the streamlining of business models, corporate and group structures of banks across the Eurozone?
\end{abstract}

Keywords: Banking Union, Single Supervisory Mechanism, Single Resolution Mechanism, Banking Regulation, Bank Corporate Governance

\section{$1 \quad$ Introduction}

As envisaged by the relevant legal instruments, the Banking Union will dramatically change the way credit institutions and banking groups are supervised across the Eurozone. ${ }^{1}$ Designed

\footnotetext{
* Professor of Private Law, Commercial Law, Corporate and Securities Law, Eberhard-Karls-Universitaet Tuebingen, E-mail: binder@jura.uni-tuebingen.de. The paper has been prepared for the Symposium "The Banking Union and the Creation of Duties", at the European University Institute in Florence, 19 and 20 March 2015. The author gratefully acknowledges research support from the Research Center SAFE, funded by the State of Hessen initiative for research LOEWE. For numerous invaluable comments from which the present version has benefited greatly, the author would like to thank, in particular, Chiara Zilioli, Guido Ferrarini, Christos Hadjiemmanuil, Stefano Cappiello, Paul Davies and Tobias Tröger. All errors are his own.
} 
to break the vicious circle between state finances and financial stability and to enhance financial stability within the Eurozone, ${ }^{2}$ the transfer of supervisory powers from the national levels to the Single Supervisory Mechanism is likely to accomplish far more than merely the replication, at the European level, of regulatory and supervisory strategies hitherto employed within the Member States. In many respects, removing residual differences between received practices will indeed be crucial for the Banking Union's success, given the scope for national biases facilitating imprudent behaviour among regulatees on the one hand and regulatory arbitrage on the other hand, which have been characteristic of the European framework for the allocation of supervisory powers under the principle of home country control. ${ }^{3}$ Only from a truly integrated, supranational perspective, if at all, the enforcement of prudential standards is considered likely to accomplish results that will be free from the adverse incentives for national supervisors, which would otherwise uduly benefit financially weak and unstable banks. While this statement holds true for the entire range of prudential standards and policies, the present paper, adopting a legal perspective, specifically explores the likely impact of the Banking Union on the governance of credit institutions. While both the fundamental policy issues and the institutional aspects of the Banking Union have been much debated since the early stages of the political process leading to the enactment of the relevant legal framework, ${ }^{4}$

\footnotetext{
${ }^{1}$ E.g., Council Regulation (EU) 1024/2013 of 15 October 2013 conferring specific tasks on the European Central Bank concerning policies relating to the prudential supervision of credit institutions, OJ L 287/63 (hereafter: the 'SSM Regulation'), recitals 9-12; Regulation (EU) No 806/2014 of the European Parliament and of the Council of 15 July 2014 establishing uniform rules and a uniform procedure for the resolution of credit institutions and certain investment firms in the framework of a Single Resolution Mechanism and a Single Resolution Fund and amending Regulation (EU) No 1093/2010, OJ L 225/1 (hereafter: the 'SRM Regulation'), recitals 1, 5, 7-12.

${ }^{2}$ E.g., Communication from the European Commission to the European Parliament and the Council: A Roadmap Towards a Banking Union, 12 September 2012, COM(2012) 510 final, p. 3. See further infra, 3.1.

${ }^{3}$ Infra, 3.1. Under European banking regulations, the principle of home-country control is now set out in Art. 49 of Directive 2013/36/EU of the European Parliament and of the Council of 26 June 2013 on access to the activity of credit institutions and the prudential supervision of credit institutions and investment firms (...), OJ L 176/338 (hereafter: 'CRD IV'). See generally, e.g., Lisa Dragomir (2010) European Prudential Banking Regulation and Supervision. (London: Routledge), at pp. 76-8, 165-81; Christos Gortsos (2012) Fundamentals of Public International Financial Law. (Baden-Baden: Nomos), at pp. 238-43; Roel Theissen (2013) EU Banking Supervision. (The Hague: Eleven International), at pp. 32, 41, 200-3.

${ }^{4}$ See, e.g., Jens-Hinrich Binder (2013), Auf dem Weg zu einer europäischen Bankenunion? Erreichtes, Unerreichtes, offene Fragen, Zeitschrift für Bankrecht und Bankwirtschaft (2013) 25:297; Eilis Ferran (2014), European Banking Union: Imperfect, But It Can Work, available at papers.ssrn.com/abstract=2426247; id. (2014), European Banking Union and the EU Single Financial Market: More Differentiated Integration, or Disintegration?, available at papers.ssrn.com/abstract= 2426580; id. and Valia S.G. Babis (2013), The Single Supervisory Mechanism, JCLS (2013) 13:255; Guido Ferrarini and Luigi Chiarella (2013), Common Banking Supervision in the Eurozone: Strengths and Weaknesses, available at papers.ssrn.com/abstract=2309897; Rosa M. Lastra (2013), Banking Union and Single Market: Conflict or Companionship?, Fordham Int'1 L.J. (2013) 36:1190; Kerstin Neumann (2014), The supervisory powers of national authorities and cooperation with the ECB - a new epoch of banking supervision, EuZW - Europäische Zeitschrift für Wirtschaftsrecht, Special Issue 1/2014, 9; Gunnar Schuster (2014), The banking supervisory competences and powers of the ECB, EuZW - Europäische
} 
this aspect of the new framework, despite its relevance for the future shape of banking within the Eurozone, has yet to attract broader attention.

Three relevant aspects can be identified: First, the question needs to be addressed if there will be any such impact at all (infra, 2). This question presents the simplest case of all three - the answer is in the positive, because the SSM, under the harmonised set of prudential regulations for banks applicable to all EU credit institutions both within and outside the Eurozone, ${ }^{5}$ has been given a clear mandate to enforce prudential standards for the governance of banks (broadly defined). Secondly, the question arises to what end the corresponding powers should be used. This, again, prima facie seems rather straightforward to resolve, the answer being a function both of the policy objectives of the Banking Union in general and of the relevance of governance standards for financial stability (infra, 3). These first two aspects can be addressed on a rather solid evidential basis, formed by the relevant legal instruments as well as past academic research. Thirdly, we will have to ask, by way of a conclusion and outlook to future developments, how these issues are likely to work out in practice (infra, 4). Of the three aspects, this latter one seems to follow directly from the answer to the second question. However, the ultimate impact of the Banking Union on the governance of the regulated industry, and thus, on the structure of the banking markets within the Eurozone as a whole, is likely to reflect a rather complex mix of quite heterogeneous determinants, including, for example, the ECB's judgment on relevant policies, its approach to dealing with idiosyncratic business models and corporate structures of banks, the willingness to actually reshape existing structures, its organisational capacity to integrate, and to realign, prevailing national views among its supervisory staff - as well as the future development of substantive EU banking laws.

All these different aspects directly relate to a fundamental question associated with the Banking Union as a whole: If it not only serves stability-related objectives but is also supposed to foster the integration of banking markets within the Eurozone - are we to expect streamlined governance arrangements across the board as a result? In other words: Will the Banking Un-

Zeitschrift für Wirtschaftsrecht, Special Issue 1/2014, 3; Tobias H. Troeger (2014), The Single Supervisory Mechanism - Panacea or Quack Banking Regulation EBOR (2014) 15:449; Eddy Wymeersch (2014), The Single Supervisory Mechanism or "SSM", Part One of the Banking Union, available at papers.ssrn.com/abstract=2397800; from an economic perspective, see Claudia M. Buch, Tobias Körner and Benjamin Weigert (2013), Towards Deeper Integration in Europe: What the Banking Union Can Contribute, available at www.sachverstaendigenrat-wirtschaft.de/publikationen.html.

${ }^{5}$ On the one hand, the CRD IV, supra n. 3, on the other hand Regulation (EU) No 575/2013 of the European Parliament and of the Council of 26 June 2013 on prudential requirements for credit institutions and investment firms and amending Regulation (EU) No 648/2012, OJ L 176/1 (hereafter: 'CRR'). 
ion lead to the reduction of diversity with regard to the relevant arrangements in the participating Member States? These aspects inevitably give rise to a considerable degree of speculation - but are nonetheless of significant interest, perhaps not least from the perspective of non-Eurozone EU Member States which may or may not opt in to the Banking Union under the relevant provisions of the SSM and SRM Regulations. ${ }^{6}$

\section{$2 \quad$ Will the Banking Union influence bank governance?}

\subsection{Overview}

In order to explore if, and ultimately how, the creation of the Banking Union is likely to change the governance of banking institutions, it seems appropriate to start with a definition: Throughout the paper, the term "governance" will be used in a broad, non-technical sense, encompassing not just "the allocation of authority and responsibilities by which the business and affairs of a bank are carried out by its board and senior management", aspects commonly referred to as "corporate governance", 7 but also the substantive results accomplished within the corporate governance framework thus defined, i.e., both fundamental and day-to-day commercial decisions. All these very different factors and the interplay and trade-offs between them, the legal and institutional frameworks for the pursuit of the banks' business as well as the way the relevant decisions are being made on a daily basis, will ultimately shape the bank's business and funding structure and, thereby, its risk exposure and financial success.

Against this backdrop, implications of the creation of a centralised framework for banking supervision are not difficult to envisage - they will simply occur because, and to the extent that, applicable prudential standards for the creation and on-going business of banks, as well as the framework for supervision and enforcement, aim at implementing and enforcing certain qualitative or indeed quantitative standards for the taking of such decisions. In this sense, the potential implications of the creation of the Banking Union on the governance of credit institu-

\footnotetext{
${ }^{6}$ See, again, SSM Regulation, supra n. 1, recitals 4, 5, 11; SRM Regulation, supra n. 1, recitals 1, 12.

${ }^{7}$ See, using this definition, e.g., the latest version of the Basel Committee's Corporate Governance Principles, Basel Committee for Banking Supervision, Corporate governance principles for banks. Issued for comments by 9 January 2015 (October 2014), www.bis.org/publ/bcbs294.pdf, at para. 2. For a discussion of various understandings of the term "corporate governance" in relation to banks see, e.g., Peter O. Mülbert (2009) Corporate Governance of Banks after the Financial Crisis - Theory, Evidence, Reforms, EBOR 10:411, at pp. 413-5; id. and Ryan Citlau (2012), The Uncertain Role of Banks' Corporate Governance in Systemic Risk Regulation. In: H Birkmose, M Neville and K Sørensen (eds), The European Financial Market in Transition. (The Hague: Kluwer Law), at pp. 275 et seq.
} 
tions, quite simply, follow from the substantive scope of the relevant mandate. This mandate is set out by the SSM and SRM Regulations. ${ }^{8}$ These in turn refer not just to the harmonised European framework for prudential banking regulation (i.e., the CRD IV and the CRR ${ }^{9}$ ) but also to the newly harmonised framework for bank insolvency management in Europe which, especially with its provisions on preventive recovery and resolution planning, will also have a bearing on bank governance. ${ }^{10}$

As such, notwithstanding the recent changes in response to perceived lessons learnt during the global financial crisis, the harmonised set of prudential requirements for banking businesses operating within the EU is well-charted territory. ${ }^{11}$ As far as requirements related to the governance of credit institutions are concerned, the relevant provisions cover both standards to be met at the licensing stage and requirements to be met on an on-going basis. In this regard, the following remarks can be limited to an overview of the key aspects insofar as they are relevant in the context of the present paper (infra, 2.2). With regard to the corresponding enforcement powers of the European Central Bank within the Single Supervisory Mechanism (SSM), as well as to the powers granted to the Single Supervisory Board within the Single Resolution Mechanism (SRM), the picture is more complex. The new institutional arrangements will operate within a complicated setting of powers and sanctions. These are set out both by the relevant EU legislation itself and by the laws of the participating Member States which transpose those parts of the harmonised prudential banking regulations that have been promulgated by Directives not by Regulations. In this context, the ECB's powers in relation to the enforcement of the Single Prudential Rulebook, i.e., the body of delegated legislation and guidance promulgated by the European Banking Authority under the CRD IV framework, will be of particular interest (infra, 2.3). In addition, the harmonised framework for the recovery and resolution of credit institutions also comes with new powers to interfere with legal and organisational structures of institutions and groups (infra, 2.4).

\footnotetext{
${ }^{8}$ Supra, n. 1.

${ }^{9}$ Supra, nn. 3 and 5.

${ }^{10}$ See, in addition to the SRM Regulation (supra, n. 1) itself, Directive 2014/59/EU of the European Parliament and of the Council of 15 May 2014 establishing a framework for the recovery and resolution of credit institutions and investment firms (...), OJ L 173/190.

${ }^{11}$ For introductions to the substantive issues, see, e.g., Dragomir, supra n. 3, at pp. 124-51 and, in great depth, Theissen, supra n. 3, at pp. 227-691 (but note that these sources deal with the set of legal instruments that preceded the enactment of the present statutory framework). For an overview of the transformation of the Basel III capital accord to EU law, see, e.g., Jeffery Atik (2013), EU Implementation of Basel III in the Shadow of the Euro Crisis, Rev. Banking \& Fin. L. 33:283.
} 


\subsection{The core of the mandate: prudential regulation relating to bank governance}

Within the general body of harmonised prudential regulations, requirements relating to the governance of banks and banking groups can be found both with regard to the initial licensing and on-going supervision. Under the delineation of powers within the Single Supervisory Mechanism, the ECB is responsible for the ultimate decision regarding the authorisation of all new credit institutions in participating Member States ${ }^{12}$ which, for present purposes, includes an assessment of the applicant's business plans and organisational arrangements, ${ }^{13}$ as well as of shareholders and members with qualified holdings in the respective firm ${ }^{14}$ under the national laws transposing the CRD IV. The ECB has also been made responsible for the assessment of notifications of the acquisition of and disposal of qualifying holdings by all credit institutions, ${ }^{15}$ providing it with effective control over changes in group structures. ${ }^{16}$ In terms of the on-going prudential supervision, the ECB assumes direct and - with some exceptions with regard to macroprudential tasks and tools ${ }^{17}$ - full responsibility for the supervision of those institutions in participating Member States that are not identified as 'less significant' pursuant to the criteria set out in Art. 6(4) SSM Regulation. ${ }^{18}$ Specifically, for 'significant' banks and, in addition, those institutions for which the ECB has chosen to assume direct control under Art. 6(4)(3) of the Regulation, ${ }^{19}$ the ECB will act as 'competent' (home) authority in the role as defined by general EU banking law ${ }^{20} .{ }^{21}$ In addition, it will be the consolidated supervisor

\footnotetext{
${ }^{12}$ See SSM Regulation, supra n. 1, Arts. 4(1)(a) and 14. Pursuant to Art. 14(1) of the Regulation, all applications are to be submitted to the relevant national competent authority, which will then submit a draft decision to the ECB under Art. 14(2). The ECB, however, retains the right to object to the draft decision under Art. 14(3) if it finds that the conditions for authorisation as set out by "relevant Union law are not met".

${ }^{13}$ Cf. CRD IV, supra n. 3, Art. 10.

${ }^{14}$ Cf. CRD IV, supra n. 3, Art. 14.

${ }^{15}$ SSM Regulation, supra n. 1, Arts. 4(1)(c) and 15.

${ }^{16}$ For the relevant qualitative requirements, cf. CRD IV, supra n. 3, Art. 23.

${ }^{17}$ Including, in particular, the determination of macroprudential capital buffers, for which national competent authorities retain primary responsibility under Art. 5 of the SSM Regulation (supra n. 1) (but see Art. 5(2) of the Regulation for residual powers of the ECB in this context). For the relevant legal basis for macroprudential supervision and tools in the EU framework for prudential supervision, see CRD IV, supra n. 3, Arts. 132-135; CRR, supra n. 5, Arts. 458-9. See also Arts. 101-5 of Regulation (EU) No. 468/2014 of the European Central Bank of 16 April 2014 establishing the framework for cooperation within the Single Supervisory Mechanism between the European Central Bank and national competent authorities and with national designated authorities (SSM Framework Regulation), OJ L 141/1.

${ }^{18}$ SSM Regulation, supra n. 1, Arts. 4(1), 6(4). These criteria have been specified further in both substantive and procedural respects by the provisions of Part IV of the SSM Framework Regulation, supra n. 17.

19 For a list of credit institutions currently under direct supervision by the ECB, see https://www.bankingsupervision.europa.eu/ecb/pub/pdf/ssmlistofsupervisedentities1409en.pdf?59d76de0c5663687f594250ebf228c6b.

${ }^{20}$ For the relevant definition, see CRR, supra n. 5, Art. 4(1)(40); CRD IV, supra n. 3, Art. 3(1)(36).
} 
for groups whose parent is established in one of the participating Member States. ${ }^{22}$ In these capacities, its remit is to ensure compliance with the relevant EU legislation on prudential standards for credit institutions both in the area of financial parameters ${ }^{23}$ and on requirements for "robust" corporate governance arrangements for the relevant institutions. As the latter are of particular importance within the context of the present paper, it is worth recalling the key components in detail: a general duty to implement governance practices "that ensure effective and prudent management of an institution", fit and proper requirements for the management of relevant institutions, risk management processes, internal control mechanisms, remuneration policies and practices and effective internal capital adequacy assessment processes, including Ratings Based models. ${ }^{24}$

While this constitutes a very broad mandate, which covers the full range of prudential regulations, it should be noted that it does not give rise to a fully integrated EU law agenda, however. Significantly, most of the relevant requirements are to be found in the CRD IV and the national laws transposing that instrument rather than in the CRR. Although the body of Level 2 and Level 3 delegated acts under both instruments keeps growing steadily, ${ }^{25}$ the prudential regulation of banks even under CRD IV continues to be, to some extent, based on national transposition in each Member State. In principle, this will also be the case within the Banking Union, where the ECB is expressly required to "apply all relevant Union law, and where this Union law is composed of Directives, the national legislation transposing those Directives."26 Where the relevant Union law is in the form of Regulations - i.e., in particular, the CRR -, and where currently those Regulations explicitly grant options for Member States, the ECB

\footnotetext{
${ }^{21}$ SSM Regulation, supra n. 1, Art. 4(1)(b), (2) and Art. 9(1).

${ }^{22}$ Ibid., Art. 4(1)(g).

${ }^{23}$ Specifically: own funds requirements, securitisation, large exposure limits, liquidity, leverage and corresponding reporting and disclosure requirements, see SSM Regulation, supra n. 1, Art. 4(1)(d).

${ }^{24}$ Ibid., Art. 4(1)(e). For the corresponding provisions in the harmonised EU legislation on prudential regulations, see CRD IV, supra n. 3, Art. 88 (general duty to implement sound governance arrangements), Art. 91 (fit and proper requirements). On risk management requirements and internal control, including internal capital adequacy assessment processes, see, among others, CRD IV, Arts. 74(1) and (2), 76-86, and CRR, supra n. 5, Arts. 103 et seq., 144(1), 145, 169 et seq., 186 et seq., 207(4), 209(3), 213(2), 221, 225(2) and (3), 244(4), 259(3), 286 et seq., 293, 367 et seq., 312(2), 320 et seq., 376. On requirements relating to remuneration policies, see CRD IV, Arts. 71(1), 76(2), 92-95.

25 For an overview of the relevant powers and for the relevant work schedule, see www.eba.europa.eu/regulation-and-policy/single-rulebook (including a link to an "interactive single rulebook", which presents the relevant Level 2 and 3 measures by way of reference to the relevant Level 1 instruments).

${ }^{26}$ SSM Regulation, supra n. 1, Art. 4(3)(1).
} 
"shall apply also the national legislation exercising those options", ${ }^{27}$ which will inevitably and considerably - reduce the scope for existing national differences in this regard.

To what extent the delineation of powers will give rise to legal uncertainty in supervisory practice remains an open question, which cannot be explored further in the context of the present paper. ${ }^{28}$ At any rate, the ECB will be subject to binding regulatory and implementing technical standards developed by EBA and adopted by the Commission, as well as to "the provisions (...) on the European supervisory handbook developed by EBA". The SSM will thus be operating, in principle, within the same substantive framework that applies across the EU as a whole, and be bound to the same Level 1-3 acts that apply outside the Eurozone. In this context, it is worth noting that the ECB, under the SSM Regulation, has been given an express mandate to "adopt guidelines and recommendations" and, in addition, to "adopt regulations (...) to the extent necessary to organise or specify the arrangements for the carrying out of the tasks conferred to it by this Regulation". ${ }^{29}$ Arguably, these powers should be narrowly construed, not just in the light of the wording of the rlevant provisions, which appears to be restricted to matters of coordination between the different levels of authorities within the SSM, but also in order to avoid conflicts with the EBA's role in specifying further the substantive content of EU prudential banking regulation. ${ }^{30}$ The limits of these powers have yet to be tested, and how the ECB itself will apply them in practice remains to be seen. To date, the focus of the relevant rule-making activities has been on the institutional arrangements and the framework for cooperation between the ECB and the national competent authorities within the SSM ${ }^{31}$ while substantive issues so far have only been addressed in the ECB's "Guide to banking supervision", 32 a non-technical document of introductory nature. Even if it refrains from applying its rule-making powers in relation to substantive matters of prudential requirements, however, the ECB's influence on the interpretation and implementation of the harmo-

\footnotetext{
${ }^{27}$ Id.

${ }^{28}$ See, for further discussion, Schuster, supra n. 4, at pp. 8-9.

${ }^{29}$ SSM Regulation, supra n. 1, Art. 4(3)(2).

${ }^{30}$ See, on the latter aspect, Elke Gurlit, The ECB's relationship to the EBA, EuZW - Europäische Zeitschrift für Wirtschaftsrecht, Special Issue 1/2014, 14, at 17.

${ }^{31}$ See, in particular, the SSM Framework Regulation, supra n. 17. For a list of other relevant legal acts, see https://www.bankingsupervision.europa.eu/legalframework/ecblegal/framework/html/index.en.html.

32 ECB, Guide to banking supervision (November 2014), available at https://www.bankingsupervision.europa.eu/ecb/pub/pdf/ssmguidebankingsupervision201411.en.pdf?404fd6cb61 dbde0095c8722d5aff29cd. The document fulfills a commitment made in the Interinstitutional Agreement of 6 November 2013 between the European Parliament and the European Central Bank on the practical modalities of the exercise of democratic accountability and oversight over the exercise of the tasks conferred on the ECB within the framework of the Single Supervisory Mechanism, OJ L 320/1.
} 
nised framework for prudential banking regulation will undoubtedly be substantial. In principle, it will be free to follow functional approaches, inspired by the underlying policy objectives rather than prevailing national concepts and biases, in this respect.

For banks not under the direct supervision of the ECB, its mandate is essentially restricted to coordinating the residual national policies, which shall be done through "regulations, guidelines or general instructions". ${ }^{33}$ As of early 2015, the supervisory practice in this respect has yet to emerge. In its "Guide to banking supervision", the ECB envisages a cooperative approach between itself and the national competent authorities (NCA), which includes the participation of ECB staff in certain supervisory activities under the auspices of the relevant NCA, with the oversight of the NCAs assigned to a special Directorate General within the ECB (DG Micro-Prudential Supervision III). ${ }^{34}$

\subsection{On-going supervision and enforcement}

In line with its mandate, the ECB has been provided with a comprehensive set of supervisory and investigatory powers, as well as sanctioning powers. Just as the mandate itself, the general principle in this regard is one of cooperative interaction between the national and the European levels. This includes a wide range of rights of information and the right to conduct investigations vis-à-vis regulated institutions and relevant persons, ${ }^{35}$ as well as to conduct onsite inspections. ${ }^{36}$ In addition to the right to withdraw an institution's authorisation, ${ }^{37}$ which is of little relevance in the present context, the ECB is given the right to require its regulatees "to take the necessary measures at an early stage to address relevant problems" in a number of specified circumstances, which essentially include the violation of any EU law prudential requirements and, specifically, cases where "the arrangements, strategies, processes and mechanisms implemented by the credit institution and the own funds and liquidity held by it do not ensure a sound management and coverage of its risks". ${ }^{38}$ These powers provide the ECB with a fairly comprehensive set of specific options with regard to a wide range of organisational is-

\footnotetext{
${ }^{33}$ SSM Regulation, supra n. 1, Art. 6(5) and (7).

${ }^{34}$ ECB, Guide, supra n. 32 paras. 85 et seq.

${ }^{35}$ SSM Regulation, supra n. 1, Arts. 10 and 11.

${ }^{36}$ Ibid., Arts. 12 and 13.

${ }^{37}$ For details, see ibid., Art. 14.

${ }^{38}$ Ibid., Art. 16(1) and, for further specification, Art. 16(2).
} 
sues, as well as financial and business decisions. ${ }^{39}$ Notably, this expressly includes powers to "require the reinforcement of the arrangements, processes, mechanisms and strategies" 40 and "to restrict or limit the buisness, operations or network of institutions or to request the divestment of activities that pose excessive risks to the soundness of an institution" 41 , thus allowing for quite far-reaching interference with regard to both organisational issues and individual business activities.

To the extent that national laws provide for powers that are not covered by these provisions, the ECB can, in its own right, make use also of these powers, ${ }^{42}$ which may further fill existing loopholes. ${ }^{43}$ This could be of particular relevance where national laws transposing the harmonised prudential standards provide the NCA with a right to actively participate in board and/or shareholders' meetings, ${ }^{44}$ which could be used as an effective tool to influence specific business decisions but is not included in the statutory powers of the ECB under the SSM Regulation. Finally, the ECB may require NCAs to make use of their statutory powers under and in accordance with the relevant national laws. ${ }^{45}$

In terms of sanctioning powers, the delineation of powers between the ECB and the NCAs reflects the split legal mandate. As a rule, the ECB will be directly responsible for the imposition of sanctions for breaches of directly applicable EU law, whereas NCAs, on the initiative of the ECB, retain responsibility for imposing sanctions for breaches of national laws transposing EU standards. ${ }^{46}$ While the SSM Regulation lays out the maximum amount of penalties that can be imposed by the ECB in its own right ${ }^{47}$ and, in addition, a general requirement that

\footnotetext{
${ }^{39}$ See, for further discussion, Schuster, supra 4, at p. 9.

${ }^{40}$ SSM Regulation, supra n. 1, Art. 16(2)(b).

${ }^{41}$ Ibid., Art. 16(2)(e).

${ }^{42}$ Ibid., Art. 9(1)(2).

${ }^{43}$ Schuster, supra 4, at p. 9.

${ }^{44}$ Cf., e.g., German Gesetz über das Kreditwesen (Kreditwesengesetz), 9 September 1998, Bundesgesetzblatt, Part I, p. 2776, [Banking Act], § 44(4) as amended.

45 Ibid., Art. 9(1)(3).

${ }^{46}$ Ibid, Art. 18(1) and (5), respectively.

${ }^{47}$ See, again, ibid., Art. 18(1): "penalties of up to twice the amount of the profits gained or losses avoided because of the breach where those can be determined, or up to $10 \%$ of the total annual turnover of a legal person in the preceding business year". For further discussion, see Sven H. Schneider (2014), Sanctioning by the ECB and national authorities within the Single Supervisory Mechanism, EuZW - Europäische Zeitschrift für Wirtschaftsrecht, Special Issue 1/2014, 18.
} 
all sanctions be effective, proportionate and dissuasive, ${ }^{48}$ the determination of a more specific sanctioning framework is left to the ECB's rulemaking. ${ }^{49}$

\subsection{Powers relating to recovery and resolution}

Following major substantive convergence of bank resolution techniques worldwide ${ }^{50}$ and within Europe, where the 2014 Bank Recovery and Resolution Directive (BRRD) ${ }^{51}$ has recently implemented international best practice in the field,${ }^{52}$ the regulatory influence on bank governance is no longer confined to traditional prudential regulation alone. In addition, recovery and resolution plans and corresponding powers to preventively influence business and funding models, as well as corporate and group structures are attracting increasing attention as a vehicle for regulatory authorities to accomplish potentially drastic changes in existing practices. ${ }^{53}$ Within the Banking Union, the ECB has been made responsible for "supervisory tasks in relation to recovery plans", ${ }^{54}$ which include not just the assessment of recovery plans but, significantly, also the power to impose "structural changes" in order to remedy perceived shortcomings. ${ }^{55}$ The ECB, in this context, also replaces national competent authorities for branches of credit institutions established in third countries. ${ }^{56}$ In cases of institutions experiencing a rapid deterioration of their financial positions, the ECB is responsible for the implementation of early intervention measures prescribed by the national laws transposing the BRRD,${ }^{57}$ which include, inter alia, powers to remove members of the management body ${ }^{58}$ and

\footnotetext{
${ }^{48}$ SSM Regulation, supra n. 1, Art. 18(3).

${ }^{49}$ See SSM Framework Regulation, supra n. 17, Part X; cf. also ECB, Guide, supra n. 32, and, for further discussion of the regime, Schneider, supra n. 47, at pp. 19-23.

50 See, in particular, Basel Committee on Banking Supervision (2010) Report and Recommendations of the Cross-Border Bank Resolution Group, available at www.bis.org/publ/bcbs169.pdf; Financial Stability Board (October 2011) Key Attributes of Effective Resolution Regimes for Financial Institutions, available at www.financialstabilityboard.org/publications/r_111104cc.pdf.

${ }^{51}$ Directive 2014/59/EU of the European Parliament and of the Council of 15 May 2014 establishing a framework for the recovery and resolution of credit institutions and investment firms (...), OJ L 173/190 (hereafter: the 'BRRD').

${ }^{52}$ See generally, e.g., Jens-Hinrich Binder (forthcoming 2015) Resolution Tools, Ch. 3. In: Jens-Hinrich Binder and Dalvinder Singh (eds) Bank Recovery and Resolution in Europe: The BRRD in Context. (Oxford University Press).

${ }^{53}$ See, for further discussion, Jens-Hinrich Binder (December 2014) Resolution Planning and Structural Bank Reform within the Banking Union, SAFE Working Paper No. 81, available at papers.ssrn.com/abstract=2540038.

${ }^{54}$ SSM Regulation, supra n. 1, article 4(1)(i).

${ }^{55}$ BRRD, supra n. 51, article 6(6).

${ }^{56}$ SSM Regulation, supra n. 1, Art. 4(2).

${ }^{57}$ See SSM Regulation, supra n. 1, Art. 4(1)(i).
} 
to require changes to the business strategy ${ }^{59}$ as well as to the legal or operational structures of the relevant institution. ${ }^{60}$

The Single Resolution Board, by contrast, will be in charge of drafting resolution plans for those institutions and groups that are under direct responsibility of the ECB. ${ }^{61}$ In this respect, the relevant provisions are to be found in the SRM Regulation, not the national laws transposing the BRRD: Article 8 of the Regulation first sets out the procedure for the development of resolution plans for those individual entities and groups for which the Board is responsible. Within this framework, the Board shall draw up the plans after consulting the ECB or relevant national competent authorities, as well as the resolution authorities in participating Member States where the relevant entities are established, and resolution authorities in nonparticipating Member States with significant branches. The Board may require national resolution authorities to prepare drafts for individual and group resolution plans ${ }^{62}$ and will issue guidelines and address instructions to national resolution authorities for such drafts. ${ }^{63}$ As for substantive requirements, the Regulation basically replicates the requirements set out for individual and group resolution plans in the BRRD. ${ }^{64}$ Just as under the BRRD, the resolution plans developed shall be based on an assessment of resolvability of the individual entities and groups. In this respect, article 10 of the SRM Regulation prescribes broadly the same procedure and substantive criteria as articles 15-18 of the BRRD for individual entities and groups, respectively. Specifically, this includes powers to require institutions to implement remedies proposed by the authority, including the reorganisation of financing arrangements, changes to the business or organisational structure and changes to the group structure. ${ }^{65}$

\section{5 "Yes it can": a summary}

Will the Banking Union influence the governance of credit institutions? As indicated before, judging from the ECB's complex mandate and its wide range of supervisory and enforcement

\footnotetext{
${ }^{58}$ See BRRD, supra n. 51, Art. 27(1)(d).

${ }^{59}$ See BRRD, supra n. 51, Art. 27(1)(f).

${ }^{60}$ See BRRD, supra n. 51, Art. 27(1)(g).

${ }^{61}$ SSM Regulation, supra n. 1, Art. 7(2).

${ }^{62}$ SRM Regulation, supra n. 1, article 8(1).

${ }^{63}$ SRM Regulation, supra n. 1, article 8(3).

${ }^{64}$ Contrast SRM Regulation, supra n. 1, article 8(6)-(12) with BRRD, supra n. 51, article 10(3)-(4) and (7) and article 12(1)-(5).

${ }^{65}$ SRM Regulation, supra n. 1, article 10(10) and (11), cf. BRRD, supra n. 51, article 10(10) and (11).
} 
powers, the answer is clearly positive. Following the implementation of the revised Basel III capital accord in the CRD IV package, ${ }^{66}$ EU banking regulation continues to serve the public interest in the preservation of financial stability, ${ }^{67}$ the protection of depositors, ${ }^{68}$ as well as the protection of free cross-border access to financial markets across all EU Member States. ${ }^{69}$ The overview of the relevant prudential requirements and the corresponding powers developed above demonstrates that governance-related aspects are considered part and parcel of this agenda. Put simply, influencing the governance of credit institutions is not just possible under the ECB's mandate, it is, in fact, a mandatory aspect of it.

Against this backdrop, it is perhaps worth noting that the general EU law framework for the prudential supervision of banks - in contrast to the new regime for bank recovery and resolution, which is more outspoken in this respect ${ }^{70}$ - does not expressly mandate competent authorities to act specifically in the interest of any of these specific high-level objectives. Nor does the SSM Regulation specifically require the ECB to do so. While the overarching policy objectives can be derived from the respective preambles to the relevant legal acts, they are not translated into a formal, principles-based broad mandate to act in the interest of financial stability, which could serve as the basis for comprehensive measures even in cases where no specific prudential requirement has been violated. Instead, in what could be described as a piecemeal approach, the relevant powers are derived from the more specific prudential requirements under both the CRD IV and CRR. This is characteristic of the harmonised body of prudential standards as a whole, and not confined to the Banking Union. In principle, under the CRD IV package, Member States continue to be free to prescribe a more comprehensive mandate, as has been done in Germany, where the Banking Act specifically requires the supervisory authority to prevent adverse developments in the banking system which could compromise customers' assets, the orderly provision of banking and other financial services or cause substantial negative externalities for the economy as a whole. ${ }^{71}$ This is then comple-

\footnotetext{
${ }^{66}$ Supra, nn. 3 and 5.

${ }^{67}$ Cf., e.g., CRD IV, supra n. 3, recitals 30, 34, 53; CRR, supra n. 5, recitals 20, 32.

${ }^{68}$ Cf., e.g., CRD IV, supra n. 3, recital 12; CRR, supra n. 5, recital 33.

${ }^{69}$ Cf., e.g., CRD IV, supra n. 3, recitals 5, 6, 12, 13; CRR, supra n. 5, recitals 11, 12, 34.

${ }^{70}$ Cf. BRRD, supra n. 51, e.g., recitals 1, 2, 16, 18, 21, 40, 53, 71 and Arts. 15, 31; see, for further discussion of the relevant policy objectives pursued by that instrument, Binder, supra n. 52 .

${ }^{71}$ Kreditwesengesetz, supra n. 44, § 6(2).
} 
mented with a very broad mandate to take all measures necessary to pursue these objectives vis-à-vis the regulated industry and responsible persons. ${ }^{72}$

The absence of similarly far-reaching powers for the ECB should not be regarded as deficient, however. As demonstrated above, the substantive content of the ECB's remit as competent authority under the harmonised EU framework for the prudential supervision of banks is fairly comprehensive. It covers not just fundamental requirements related to the funding of institutions, but also organisational issues such as risk management and other aspects of the internal governance of decision-making processes. Notwithstanding the absence of an express mandate to act in the interest of financial stability (including the protection of depositors) the given set of powers de facto amount to something rather commensurate. All in all, it is fair to conclude that the legal framework for banking supervision within the Eurozone indeed opens an almost unlimited scope for interference with the governance of credit institutions: "Yes it can" - the ECB is indeed in a very strong position to change the way banking businesses are being organised across the Eurozone. To some extent, the same applies to the SRB in its capacity as resolution authority.

\section{Should it do so - and to what end? Relevant policy objectives and selected areas of prudential supervision}

\subsection{Relevant policy objectives}

As indicated before, the Banking Union authorities should use their respective powers with a view to influencing the governance of supervised institutions if, and to the extent that, existing, heterogeneous governance regimes and practices can be proved problematic against the measure of the fundamental policy objectives the Banking Union is set to pursue. The Banking Union's impact on bank governance, in other words, is likely to be a function of the very policy objective associated with the centralisation of supervisory powers - and could, therefore, differ from the impact of the harmonised framework for prudential regulation outside the Eurozone, where prudential supervision continues to be exercised by national authorities, which enjoy some discretion with regard to the transposition and implementation of specific requirements.

\footnotetext{
${ }^{72}$ Ibid., $§ 6(3)$.
} 
In this light, it is important to note that neither the centralisation of supervisory powers within the SSM nor the convergence of regulatory standards and prudential practices, which may be anticipated as a consequence, are objectives to be pursued merely for their own sake. Particularly within the European Union, the crisis had exposed fundamental weaknesses associated with the delineation of powers under the principle of home country control. ${ }^{73}$ From the start, that principle had been conceived as a means to enhance the effectiveness of banking supervision, by ensuring the allocation of supervisory powers in those jurisdictions where the relevant legal entities and governance arrangements are located. ${ }^{74}$ As the corresponding substantive prudential standards left ample room for different interpretations by national authorities, however, the outcome was ambivalent and, in some cases, even negative. Conflicting national interests among regulatory agencies from different jurisdictions, as well as incentives for the regulated industry to move activities into subsidiaries in jurisdictions with less restrictive enforcement standards are widely considered a direct result of such weaknesses. ${ }^{75}$ Upon the insolvency of financial institutions, this environment has been perceived to be conducive to supervisory forbearance on the part of the relevant home country authorities even where decisive interference with an ailing bank's affairs would have led to a reduced financial burden in the medium and long term ${ }^{76}$ and would be far more beneficial to long-term market discipline.

\footnotetext{
${ }^{73}$ For the legal foundation of which, see supra n. 3.

${ }^{74}$ Cf., e.g., Charles Goodhart (2011), The Basel Committee on Banking Supervision. A History of the Early Years 1974-1997, pp. 96 et seq.; George A. Walker (2001), International Banking Regulation. Law Policy \& Practice, pp. 86 et seq.; Bryan S. Strawbridge (2010), A Ship Without a Captain at the Helm: The Need for the Development and Implementation of a Supra-National Prudential Supervisor to Oversee the European Union Financial Sector, Ind. Int'1 \& Comp. L. Rev. 20:111, at pp. 122-128.

${ }^{75}$ Cf., e.g., Strawbridge, supra n. 74, at pp. 128-130; on the conflicting national interest and the impact on financial stability in a home country control environment, see generally, e.g., Jean Dermine (2006), European Banking Integration: Don't Put the Cart before the Horse, Financial Markets Institutions \& Instruments 15:57, at pp. 89 et seq.; Richard J. Herring (2007), Conflicts Between Home and Host Country Prudential Supervisors, in: DD Evanoff, GG Kaufman and JR LaBrosse (eds.), International Financial Instability. Global Banking and National Regulation (New Jersey: World Scientific), 201; Alessandro Prati and Garry J. Schinas (2000), Financial Stability in European Economic and Monetary Union, in C Goodhart (ed.), Which Lender of Last Resort for Europe? (London: Central Banking Publications), 86, at pp. 113-4; Dirk Schoenmaker (2013), Governance of International Banking. The Financial Trilemma (Oxford: Oxford University Press), pp. 69-71; for a legal perspective, see Tobias H. Tröger (2013), Organizational Choices of Banks and the Effective Supervision of Transnational Financial Institutions 48:177, at pp. 186 et seq., 200 et seq., 214 et seq. And see, for further discussion, Binder, supra n. 4, at p. 300; Ferrarini and Chiarella, supra n. 4, at pp. 7-10; Wymeersch, supra n. 4, at pp. 5-6.

${ }^{76}$ Cf., e.g., Torsten Beck (2012), Why the rush? Short-term crisis resolution and long-term bank stability, in: id. (ed.), Banking Union for Europe - Risks and Challenges (London: Centre for Economic Policy Research, available at www.voxeu.org/sites/default/files/file/Banking_Union.pdf), 37, at p. 39; Wim Fonteyne et al., 'Crisis Management and Resolution for a European Banking System', IMF Working Paper WP/10/70 (March 2010), available at www.imf.org/external/pubs/ft/wp/2010/wp1070.pdf, pp. 12 et seq.; Charles A. E. Goodhart, Funding arrangements and burden sharing in banking resolution, in: Banking Union for Europe, ibid., pp. 105-106; Rishi Goyal et al., A Banking Union for the Euro Area, IMF Staff Discussion Note (13 February 2013),
} 
Against this backdrop, the centralisation of supervisory powers thus has been promoted not just in the interest of deeper market integration and a stronger banking system within the Eurozone, but also as a tool to foster financial stability both inside and outside the Monetary Union. ${ }^{77}$ The political intention to break the vicious circle between state finances and financial stability and to enhance financial stability within the Eurozone, which has been much debated as a key rationale for the reform project in response to the still on-going Euro crisis, ${ }^{78}$ should be seen as adding just a different facet to the same reasoning: From the perspective of prudential regulation, national banking systems surely never should have been allowed to become deeply entangled with the funding of their respective national budgets as key investors in domestic public debt in a number of European markets. As the financial crisis turned into a sovereign debt crisis for some Eurozone countries from 2009, the risks this would evoke for the stability of the respective banking systems became obvious, Greece, Cyprus and Ireland providing just the most drastic examples so far. ${ }^{79}$ While the exploitation of domestic banks as providers of funding to the national fiscus arguably should have been avoided in order to prevent a sovereign debt crisis turning back into a banking crisis, the incentives for the relevant NCA to enforce such a policy in the run-up to the crisis evidently were small. Conceptually, a centralised authority which did not suffer from similar fiscal biases, by contrast, could and should have been expected to have exercised a stronger influence on the regulated industry to prevent it from building up excessive exposure to the relevant fiscus. ${ }^{80}$

To sum up, the Banking Union, not least, should be seen as an attempt to reduce risks for financial stability that are connected with national biases and fiscal interests of the relevant home jurisdictions. For the purposes of the present paper, this objective can be classified as the fundamental benchmark against which the likely impact of centralised supervision within

www.imf.org/external/pubs/ft/sdn/2013/sdn1301.pdf, para. 7; Vasso Ioannidou (2012), A first step towards a banking union, in: T Beck (ed.), Banking Union for Europe pp. 87, 89; see also Dirk Schoenmaker and Arjen Siegmann, Efficiency Gains of A European Banking Union (11 February 2013), http://ssrn.com/abstract=2214919; for a general discussion see Paul Cavelaars et al., Key Challenges for Financial Supervision After the Crisis (June 2013), www.wrr.nl/fileadmin/nl/publicaties/PDF-webpublicaties/ Web_71.pdf, pp. 19-20.

${ }^{77}$ See, for further discussion, Binder, supra n. 4, at pp. 300-1; Ferrarini and Chiarella, supra n. 4, at pp. 16-19.

${ }^{78}$ E.g., Communication from the European Commission to the European Parliament and the Council: A Roadmap Towards a Banking Union, 12 September 2012, COM(2012) 510 final, p. 3. See, for further discussion in this respect, Binder supra n. 4, at pp. 302-3; Ferrarini and Chiarella, supra n. 4, pp. 16-7.

${ }^{79}$ See also Tröger, supra n. 4, at pp. 45960 (discussing the examples of the Spanish and Cypriot banking crises as triggers for the political move towards the Banking Union).

${ }^{80}$ E.g., Goyal, supra n. 76, at para. 7; Andy W. Mullineux, The Eurozone Crisis: Escaping the ,Doom Loop' (12 November 2012), http://ssrn.com/abstract=2176670, pp. 28 et seq., 34 et seq.; Schoenmaker and Siegmann, supra n. 76; cf. also Ferrarini and Chiarella, supra n. 4, at pp. 16-7. 
the Single Supervisory Mechanism should be evaluated. As the ultimate success of the Banking Union will be measured against this objective, any supervisory interference with corporate governance arrangements, decision-making processes and the substantive content of day-today commercial decisions of banks in participating Member States should serve this purpose, and the outcome should be justifiable on these grounds.

In this context, it should be noted that these considerations do not bear out an unmitigated mandate for a "one size fits all" approach. The convergence of both regulatory standards on the one hand and governance arrangements in banks on the other hand, towards whatever will turn out to be accepted as best practice, is certainly consistent with this policy framework, and it could, in addition, foster further integration of regional markets. However, this is not supposed to give rise to the dissolution of local or regional market structures which, in fact, the ECB is expressly required to respect to the extent possible. ${ }^{81}$ Changes to pre-existing arrangements and structures as a result of the implementation of the Banking Union therefore should be legitimate only where they are necessitated by the specific policy objectives discussed above. In a way, this could be understood as a clarification of the general principle of proportionality, which, in the SSM Regulation, has been addressed only in a limited way. ${ }^{82}$ Using some of the specific prudential requirements mentioned above as examples, the following subsections will explore some of the potential implications for future practice.

\subsection{Business organisation}

\subsubsection{General prudential requirements}

Prima facie, the regulation of the fundamental organisational arrangements in regulated institutions and groups presents a rather clear-cut case in this respect. Already before the global financial crisis of 2007-9, sound organisational arrangements within banks had been widely regarded as important determinants for the safety and soundness of credit institutions. After

\footnotetext{
${ }^{81}$ Cf. SSM Regulation, supra n. 1, recital 17: "When carrying out the tasks conferred on it, and without prejudice to the objective to ensure the safety and soundness of credit institutions, the ECB should have full regard to the diversity of credit institutions and their size and business models, as well as the systemic benefits of diversity in the banking industry of the Union."

${ }^{82}$ Cf., in particular, SSM Regulation, supra n. 1, recital 55 and Art. 17(3) (relating to the imposition of penalties). And see ECB, Guide, supra n. 32, at p. 8 (expressly recognising the proportionality as a guiding principle for the supervisory policies within the SSM).
} 
the crisis, this view has widely been accepted not least by international policymakers ${ }^{83}$ and the EU. ${ }^{84}$ In European banking regulation, the preamble to the CRD IV is particularly outspoken in this regard. As it sets out both the relevant policy agenda and the underlying rationale with the utmost clarity, it deserves to be quoted at some length:

"Weaknesses in corporate governance (...) have contributed to excessive and imprudent risk-taking in the banking sector which has led to the failure of individual institutions and systemic problems in Member States and globally. (...) In some cases, the absence of effective checks and balances within institutions resulted in a lack of effective oversight of management decision-making, which exacerbated short-term and excessively risky management strategies. The unclear role of the competent authorities in overseeing corporate governance systems in institutions did not allow for sufficient supervision of the effectiveness of the internal governance processes.

In order to address the potentially detrimental effect of poorly designed corporate governance arrangements on the sound management of risk, Member States should introduce principles and standards to ensure effective oversight by the management body, promote a sound risk culture at all levels of credit institutions and investment firms and enable competent authorities to monitor the adequacy of internal governance arrangements. (...). $" 85$

If one takes these formulations at face value, they could be read like a rather clear-cut agenda not just for banking supervisors generally, but also for the ECB as sole supervisor in the Banking Union. Reality is more complex, however. To be sure, the relevant standards constitute a significant part of the corporate governance-related provisions of the CRD IV and will, as such, definitely form an important part of the ECB's mandate. The range of relevant issues

\footnotetext{
${ }^{83}$ See, characteristically, e.g., Basel Committee, supra n. 7, para. 1: "Effective corporate governance is critical to the proper functioning of the banking sector and the economy as a whole. Banks serve a crucial role in the economy by intermediating funds from savers and depositors to activities that support enterprise and help drive economic growth. Banks' safety and soundness are key to financial stability, and the manner in which they conduct their business, therefore, is central to economic health. Governance weaknesses at banks that play a significant role in the financial system can result in the transmission of problems across the banking sector and the economy as a whole." And see, for a broad overview of the relevant issues, OECD (2009), Corporate Governance and the Financial Crisis: Key Findings and Main Messages, available at www.oecd.org/daf/ca/corporategovernanceprinciples/43056196.pdf.

${ }^{84} \mathrm{See}$, in particular, Commission, Green Paper: Corporate governance in financial institutions and remuneration policies (2 June 2010), COM(2010) 284 final, pp. 2-9.
}

${ }^{85}$ CRD IV, supra n. 3, recitals 53 and 54. 
is rather broad: Leaving aside the more fundamental powers with regard to the assessment of qualifying holdings discussed above,${ }^{86}$ it begins with fit and proper requirements for directors and managers, including requirements for the time to be committed by board members to the performance of their duties,${ }^{87}$ and extends to the requirement for boards to define, and implement, "governance arrangements that ensure effective and prudent management of an institution, including the segregation of duties in the organisation and the prevention of conflicts of interest", ${ }^{88}$ as part of Pillar II of the Basel III arrangements. ${ }^{89}$ The core provision is to be found in Art. 74(1) CRD IV, pursuant to which

“institutions shall have robust governance arrangements, which include a clear organisational structure with well-defined, transparent and consistent lines of responsibility, effective processes to identify, manage, monitor and report the risks they are or might be exposed to, adequate internal control mechanisms, including sound administration and accounting procedures, and remuneration policies and practices that are consistent with and promote sound and effective risk management."

Such arrangements are to be "comprehensive and proportionate to the nature, scale and complexity of the risks inherent in the business model and the institution's activities," 90 and they are to be complemented, in due course, by EBA guidelines. ${ }^{91}$ While these provisions certainly form part of the supervisory agenda, it is difficult to predict whether, to what extent and, indeed, in which respects supervisory practice under the Banking Union will look any different from previous policies adopted by NCAs for two reasons.

First, full, technical convergence of both supervisory standards and governance arrangements in the relevant fields is certainly made difficult by the wide variety of existing business models, corporate and group structures across the Eurozone. Even within the group of "significant" banks under direct supervision of the ECB, ${ }^{92}$ the prevailing arrangements are highly

\footnotetext{
${ }^{86}$ See, again, supra n. 15 and accompanying text.

${ }^{87}$ See, again, ibid., Art. 91. Pursuant to Art. 91(12), these requirements are to be specified further in EBA guidelines, which have not yet been released as of February 2015.

${ }^{88}$ See, again, CRD IV, supra n. 3, Art. 88(1).

${ }^{89}$ On which, see also further infra, 3.4.

${ }^{90}$ Ibid., Art. 74(2).

${ }^{91}$ Ibid., Art. 74(3). For the time being, the relevant document is EBA Guidelines on Internal Governance (GL 44) (27 September 2011), available at https://www.eba.europa.eu/documents/10180/103861/EBA-BS-2011-116final-EBA-Guidelines-on-Internal-Governance-\%282\%29_1.pdf.

92 Cf., again, supra n. 18 and accompanying text.
} 
heterogeneous, which in itself should preclude "one size fits all" approaches and militates in favour of tailored solutions sensitive to the individual circumstances of each particular case. ${ }^{93}$ An example is the co-existence of credit institutions with one-tier boards of directors and other with (German-style) two-tier boards, where management and oversight functions are separated. The CRD IV expressly recognises the existing structural differences between the two systems, ${ }^{94}$ but, while purporting to take a neutral, functional approach, does not fully accommodate the separation of powers in two-tier systems. ${ }^{95}$ As mentioned before, the ECB, in its capacity as sole supervisor of significant banks within the Eurozone, is expressly required to respect this diversity, ${ }^{96}$ which reinforces the flexible, adaptive approach taken followed by the CRD IV. Taken seriously, this would appear to reduce the scope for the development of standardised regulatory requirements with regard to the business organisation and their promotion through supervisory enforcement. In other words: Although the development of "best practice" standards has been expressly recognised as an objective to be pursued in the future supervisory practice of the ECB, ${ }^{97}$ it may be difficult to establish in this particular field.

Second, even if standardised supervisory policies vis-à-vis the business organisation of banks were pursued, its development would likely turn out to be difficult. Despite a large amount of comparative, empirical research on the relevance of corporate governance on the safety and soundness of banks in the aftermath of the global financial crisis, the available evidence to date has been restricted to general aspects of corporate governance indicators (in particular, the relative importance of shareholder influence). ${ }^{98}$ It is, however, somewhat inconclusive

93 This is corrobated also by empirical evidence, see Marc van Essen, Peter-Jan Engelen and Michael Carney (2013), Does "Good Corporate Governance Help in a Crisis? The Impact of Country- and Firm-Level Governance Mechanisms in the European Financial Crisis", Corp. Gov. Int'l Rev. 21:201 (finding that universal corporate governance standards may be ineffective because the efficacy of governance mechanisms may be contingent upon organisational and environmental circumstances).

${ }^{94}$ CRD IV, supra n. 3, recitals 55-7.

${ }^{95}$ See, for further discussion, Peter O. Mülbert (2015), The CRD IV framework for banks' corporate governance, . But note that the conceptional distinction, in practice, well facilitates broadly similar functional designs, for example with regard to the structure and composition of board committees.

${ }^{96}$ See, again, supra n. 81 and accompanying text.

${ }^{97}$ Cf. ECB, Guide, supra n. 32, at p. 7.

98 See, e.g., Deniz Anginer et al. (2014), Corporate Governance and Bank Insolvency Risk. International Evidence, available at http://ssrn.com/abstract=2491490 (finding, inter alia, that bank insolvency risk is positively associated with the shareholder-friendliness of banks); Marco Becht, Patrick Bolton and Alisa Röell, Why bank governance is different (2011), Oxford Rev. Econ. Pol'y 3:437 (pointing to inconclusive evidence as to the role of board incompetence, as well as different ownership structures, and highlighting the available evidence with regard to insufficient internal control mechanisms); Andrea Beltratti and René M. Stulz (2012), The credit crisis around the globe: Why did some banks perform better?, J. Fin. Econ. 105:1 (finding, inter alia, that "banks with more shareholder-friendly boards performed significantly worse during the crisis than other banks, were not less 
when it comes to fundamental questions of business organisation. To be sure, individual governance failures, such as insufficient checks and balances in lending and investment decisions or risk management arrangements, may not be difficult to be detected as the analysis of the causes of individual failures makes progress, and selected issues for reform certainly can be identified. ${ }^{99}$ Under the CRD IV package, the relevant provisions continue to form part of the framework for the Supervisory Review Process (SRP) and the Internal Capital Adequacy Assessment Process (ICAAP), and will be dealt with in this context. ${ }^{100}$ While it is impossible to explore the empirical evidence further within the context of the present paper, one cannot escape the conclusion that, beyond technical adjustments to risk management requirements, the available evidence does not (as yet) support the development of more or less comprehensive positive organisational models that could be promoted as best practice across the board among Eurozone banks. It is, perhaps, indicative of these problems that available evidence does not appear to corroborate the notion that regulatory intereference with the organisation of banks will improve the safety and soundness of banks. ${ }^{101}$

In sum, the above considerations suggest that the agenda for the ECB in terms of the enforcement of prudential standards relating to the business organisation of regulated banks will

risky before the crisis, and reduced loans more during the crisis"); David H Erkens, Mingyi Hung and Pedro Matos (2012), Corporate governance in the 2007-2008 financial crisis: Evidence from financial institutions worldwide, J. Corp. Fin. 18:389 (finding that "(1) firms with higher institutional ownership took higher risks before the crisis, which resulted in larger shareholder losses during the crisis, and (2) firms with more independent boards raised more equity capital during the crisis, which led to a wealth transfer from existing shareholders to debtholders"); Luc Laeven and Ross Levine (2009), Bank Governance, Regulation and Risk Taking, J. Fin. Econ. 93:259 (finding that "bank risk taking varies positively with the comparative power of shareholders within the corporate governance structure of each bank"); as well as the exhaustive collection of papers in James R. Barth, Chen Lin and Clas Wihlborg (eds.) (2012), Research Handbook on International Banking and Governance (Cheltenham: Edward Elgar) and the survey by Jakob de Haan and Razvan Vlahu (2013), Corporate Governance of Banks: A Survey, DNB Working Paper No. 386, available at www.dnb.nl/en/binaries/Working\%20Paper\%20386_tcm47-294339.pdf. For a policy oriented overview (without detailed own empirical basis), see also Grant Kirkpatrick (2009), The Corporate Governance Lessons from the Financial Crisis, OECD Journal: Financial Market Trends 61.

${ }^{99}$ See, e.g, reviewing the available evidence, e.g., Becht, Bolton and Röell (2011), at pp. 455-6; Klaus J. Hopt (2012), Corporate Governance of Banks After the Financial Crisis, in: E Wymeersch, K Hopt and G Ferrarini (eds.), Financial Regulation and Supervision (Oxford: Oxford University Press), 337, at paras. 11.16-11.23; see also Jean Dermine (2013), Bank Corporate Governance, Beyond the Global Banking Crisis, Fin. Markets, Institutions \& Instruments 22:259; Kirkpatrick, supra n. 98; René M. Stulz (2014), Governance, Risk Management, and Risk-Taking in Banks, available at http://ssrn.com/abstract=2457947; Jaap Winter, The Financial Crisis: Does Good Corporate Governance Matter and How to Achieve It?, in: Financial Regulation and Supervision, ibid., paras. 12.21 et seq.

100 Infra, 3.4.

${ }^{101}$ Cf. Aslı Demirgüç-Kunt and Enrica Detragiache (2009), Basel Core Principles and Bank Soundness, available at http://ssrn.com/abstract=1509196; and see, questioning the focus on governance-related prudential standards, Christoph Van der Elst (2015), Corporate Governance and Banks: How Justified is the Match?, available at http://ssrn.com/abstract=2562072. 
be one of individualised approaches, tailored to the specific characteristics of the relevant firm and group, rather than lead to the outright promotion of general standards of "best practice", however defined. This does not rule out the emergence of commonly accepted standards over time, which is not unlikely to reflect the functional approach advocated in international standards and may be furthered by supervisory interventions on the basis of the powers analysed above. For the time being, however, a more comprehensive convergence with regard to the technical details of existing organisational arrangements on the initiative of the ECB is unlikely to be expected. Given the need to align regulatory practices with the existing divergence of business models and corporate structures, this should be welcomed - and does not preclude substantial improvements in terms of the quality of supervision.

\subsubsection{Implications on recovery and resolution planning on organisational arrangements}

A different course of action, with a more aggressive tendency towards streamlining existing business models and corporate structures, may, perhaps, be envisaged on the basis of the powers given to the ECB and the SRB in connection with the assessment of recovery and resolution plans. As discussed above, both instruments, in part in connection with the relevant provisions in the BRRD, open the door to substantial interference with business and funding models as well as corporate and group structures, in cases where the existing arrangements are deemed to be inconducive to swift and effective measures aiming at the recovery or resolution in the proximity of, or in actual, insolvency. ${ }^{102}$ The full scope of such powers has been analysed elsewhere ${ }^{103}$ and cannot be explored in detail within the present paper. It should be noted, however, that impediments to recovery and resolution associated with the relevant institution's or group's organisation are not unlikely to be similar in many cases, which could warrant more standardised remedial action on the part of either the ECB or the SRB. The relevant factors have only insufficiently been explored so far. ${ }^{104}$ However, both authorities will be likely to develop their understanding of the relevant factors over time, which could rather justify a tendency towards a more intrusive top-down reengineering of existing structures from

\footnotetext{
102 See, again, SSM Regulation, supra n. 1, Art. 4(1)(i) in connection with the national laws transposing BRRD, supra n. 51, Arts. 5-9 (on recovery planning); SRM Regulation, supra n. 1, Arts. 8-9 (on resolution planning) and 10 (on the "assessment of resolvability" and corresponding powers for the SRB). And see already supra 2.4.

${ }^{103}$ See Binder, supra n. 53.

${ }^{104}$ See Jens-Hinrich Binder (2015), Ring-Fencing: An Integrated Approach with Many Unknowns, EBOR
} 
their part than could be justified on the grounds of the general prudential requirements discussed above.

\subsection{Remuneration of directors and managers}

In recent years, the remuneration of directors and managers of banks has attracted much attention as a source of ill-designed incentive structures that may have triggered a wide-spread trend towards excessive risk-taking prior to the global financial crisis, although the available empirical evidence appears to be, again, rather vague. ${ }^{105}$ In line with earlier FSB work, ${ }^{106}$ both the CRD IV and the CRR stress the need to combat such incentives by realigning compensation practices with the long-term interest in the safety and soundness of institutions. ${ }^{107}$ The CRD IV lays down qualitative and quantitative restrictions in this respect, which will be complemented by EBA guidelines, ${ }^{108}$ as well as specific responsibilities for each bank's remuneration committee, ${ }^{109}$ while the CRR imposes corresponding transparency requirements. ${ }^{110}$ While details are beyond the scope of the present paper, it should be clear that remuneration policies open yet another important field of prudential regulation where the transfer of regulatory and supervisory powers from the national to the European level could lead to substantial convergence of existing practices over time. It is certainly likely that, in its capacity as competent authority within the CRD IV/CRR framework, the ECB's assessment of existing arrangements within the regulated institutions will follow consistent patterns and not be overly reflective of residual differences in national perspectives. Whether or not this will lead to different standards than would be applied to credit institutions outside the Eurozone, however, remains to be seen. In this context, the scope for the development of individual strategies by supervisory authorities is rather limited, given the extent to which remuneration standards

\footnotetext{
105 See, in addition to the general studies on corporate governance quoted supra n. 98, e.g., Rüdiger Fahlenbrach and René M. Stulz (2011), Bank CEO Incentives and the Credit Crisis, J. Fin. Econ. 99:11 (finding, inter alia, that banks with CEO incentives tied with shareholder interests performed worse than others during the global financial crisis); Guido Ferrarini and Maria Cristina Ungureanu, An Overview of the Executive Remuneration Issue Across the Crisis. In H Birkmose, M Neville and K Sørensen (eds), Boards of Directors in European Companies - Reshaping and Harmonising their Organisation and Duties (The Hague: Wolters Kluwer), 349. But see, identifying some key policy requirements in this area, OECD, supra 83, pp 14-29.

${ }^{106}$ Financial Stability Board (2009), Principles for Sound Compensation Practices and Implementing Standards, available at www.financialstabilityboard.org/wp-content/uploads/r_0904b.pdf.

${ }^{107}$ See CRD IV, supra n. 3, recitals 62-9; CRR, supra n. 5, recital 97.

${ }^{108}$ CRD IV, supra n. 3, Arts. 74(1), 75, 92-4, see also, for corresponding supervisory powers, Art. 104(1)(g).

${ }^{109}$ Ibid., Art. 95.

${ }^{110}$ See CRR, supra n. 5, recital 97 and Art. 450.
} 
have been harmonised on the initiative of the $\mathrm{FSB}^{111}$ and the EBA already in the past and will be harmonised further in the future. ${ }^{112}$ Given this level of international and pan-European harmonisation, the idiosyncratic impact of the Banking Union on remuneration policies may well turn out to be limited, irrespective of the broad mandate given to the ECB also in this regard.

\subsection{ICAAP and Internal Models}

Among the different governance-related prudential requirements, the framework for the implementation of Pillar 2 of the Basel III capital accord presents the most complex case, in general terms as well as for the purposes of the present paper. As noted above, ${ }^{113}$ internal risk management arrangements of banks, on which this regime focuses, have indeed been demonstrated as deficient during the run-up to the global financial crisis. While regulatory requirements on risk management arrangements and the risk culture have been a core part of substantive prudential regulation within the EU for some time, ${ }^{114}$ existing risk management regimes obviously failed to prevent the insolvencies that occurred in the years between 2007-9, which justifies efforts for further improvement in this area even if the available evidence on specific failures still appears to be weak. In this respect, the area of risk management certainly will be an important field for future regulatory intervention. At the same time, risk management practices, owing to their technical nature, could be particularly well-suited for the development of general best practice standards on the initiative of regulatory authorities, not least within the Banking Union framework where the availability of a broad range of information on various large banking institutions and their respective arrangements on the part of the ECB could turn out to be particularly conducive to the development of such standards.

\footnotetext{
${ }^{111}$ See FSB, supra n. 106, and, for the follow-up work, FSB, Implementing the FSB Principles for Sound Compensation Practices and their Implementation Standards. Third progress report (4 November 2014), available at www.financialstabilityboard.org/wp-content/uploads/r_141104.pdf.

112 For the EBA's work on remuneration policies to date, see www.eba.europa.eu/regulation-andpolicy/remuneration.

${ }^{113}$ Supra, n. 99 and accompanying text. And see OECD, supra n. 83, at pp. 31-40.

114 On the early stages up to the implementation of the Basel II capital standards with Directive 2000/12/EC of the European Parliament and of the Council of 20 March 2000 relating to the taking up and pursuit of the business of credit institutions, OJ L 126/1, see, e.g., Jens-Hinrich Binder (2008), Rechtliche Grundlagen des Risikomanagements in Banken und Finanzdienstleistungsinstituten, in: F Romeike (ed.), Rechtliche Grundlagen des Risikomanagements (Berlin: Erich Schmidt), 133, at pp. 137-47.
} 
In this context, it is worth recalling that the relevant provisions in the CRD IV package are designed specifically to allow for gradual, evolutionary ${ }^{115}$ approaches on the part of both the regulated industry and the competent supervisory authority. ${ }^{116}$ Under what is known as the Internal Capital Adequacy Assessment Process (ICAAP), the institutions themselves are required to develop sound and effective internal strategies and processes in a number of respects ${ }^{117}$ and to assess and monitor the adequacy of their capital on an ongoing basis. ${ }^{118} \mathrm{Com}$ petent authorities are then to subject the relevant arrangements to the so-called Supervisory Review Process (SRP). ${ }^{119}$ With its focus on the adequacy of individual institution's arrangements and its openness to gradual development over time on the part of both institutions and authorities, the regime could turn into a cornerstone of future regulatory policies not least within the Banking Union, where the supranational perspective of the ECB as sole supervisor could be particularly conducive to the accumulation of relevant expertise, which could then be applied across the board of directly regulated institutions. Just as with general aspects of business organisation, the ECB would still be required to respect existing differences rooted in business models and corporate structures, ${ }^{120}$ which will preclude the emergence of "one size fits all" standards also in this field. However, the more technical nature of the relevant arrangements still seems better suited for a realignment along best practice than general aspects of corporate or business organisation. Over time, this may facilitate the emergence of a body of technical standards for internal strategies and processes, driven by the ECB as part of the SRP on the basis of growing comparative regulatory expertise. To be sure, the likely result will not be uniformity of internal models, but enhanced comparability and qualitative convergence may nonetheless be expected.

In other words, both the ICAAP and the SRP could indeed form a core part of the general quest for a "sound risk culture", as prescribed by the CRD IV, ${ }^{121}$ and it could be in this respect that the ECB, qua its supranational perspective, could prove particularly influential.

\footnotetext{
${ }^{115}$ Cf. CRR, supra n. 5, recital 48.

${ }^{116}$ For an in-depth discussion, see, e.g., Theissen, supra n. 3, at pp. 666-75.

${ }^{117}$ See in addition to the provisions cited supra nn. 89 and 90, e.g., CRD IV, supra n. 3, Art. 73 (strategies for the monitoring of capital adequacy), Art. 76(1) (strategies relating to risk control), Art. 86(1), (10) and (11) (strategies relating to the monitoring of liquidity risk), Art. 103 (strategies relating to the monitoring of trading activities), Art. 182(1) (strategies relating to the operation of bank accounts and payment activities).

118 Ibid., Arts. 73-95, 108-9, see also CRR, supra n. 5, recital 96. See, for further discussion of the concept, Theissen, supra n. 3, pp. 663-8 (based on the CRD III regime, but still valid in principle).

${ }^{119}$ CRD IV, supra n. 3, Arts. 97-101. See Theissen, supra n. 3, pp. 669-74.

${ }^{120}$ See, again, supra n. 81 and accompanying text.

${ }^{121}$ CRD IV, supra n. 3, recital 54.
} 
Specifically, the same considerations apply to the development, and supervisory recognition, of internal models for the purposes of bank capital regulation. ${ }^{122}$ It is thus not surprising that this regime has been identified, by the industry itself, as a key area of concern with regard to the transfer of supervisory powers to the ECB, expressing high expectations for the improvement of supervisory standards due to the ECB's supranational perspective and expertise. ${ }^{123}$

\subsection{Summary}

All in all, the case for substantial changes to existing supervisory policies as a result of the transfer of supervisory powers from the NCA to the ECB appears to be mixed. Given the weak empirical link between general organisational aspects (e.g., board structure or the role of shareholders) and remuneration policies on the one hand and bank safety and soundness on the other hand, the case for streamlining the relevant supervisory standards and, as a result, existing arrangements in the supervised institutions is rather weak - too weak as to justify a forced convergence, which would remove the existing variety of business and funding models. With respect to the reform of existing corporate and group structures in the interest of enhanced resolvability and to the development of internal strategies as part of the ICAAP and SRP regimes, however, the picture is different. It is in these respects that the transfer of supervisory powers from the national levels to the ECB could, over time, yield the most tangible results in terms of changes to bank governance. While commonly accepted best standards for the design of fundamental aspects of bank governance hardly exist so far, the ECB (and, indeed, the SRB as the authority responsible for resolution planning for significant credit institutions) could turn out to be an influential driver of the future development of such best practice - with implications to be felt not just within the Eurozone itself.

\section{$4 \quad$ A speculative outlook and conclusion}

Where does this leave us, as of early 2015? As indicated above, how precisely the Banking Union authorities will make use of their powers with regard to the governance of banks in the years to come is, essentially, a matter of speculation. Early statements suggest that the ECB is

\footnotetext{
122 See, in particular, ibid., recitals 70 and 74, Arts. 76(2), 77(3), 101; CRR, supra n. 5, recital 70 and Arts. 143(2), 144(1)(f) and (h), 151(4), 155(1) and (4), 187-8, 221, 283-94, 362-77, 383, 390(2), 455.

${ }^{123}$ E.g., Association of Financial Markets in Europe (July 2013), Supervising cross-border banks in Europe. An industry survey in advance of implementation of the Single Supervisory Mechanism, available at www.afme.eu/WorkArea/DownloadAsset.aspx?id=9232, pp. 12-5. On the future role with regard to banks' internal models envisaged by the ECB, see ECB, Guide, supra n. 32, paras. 62-6.
} 
determined to strive for consistent application and enforcement of prudential requirements, as well as the development of "best practice" standards (where appropriate), while at the same time respecting the principle of proportionality vis-à-vis highly diverse market structures and business models across the Eurozone. ${ }^{124}$ The considerations developed in the present paper suggest that these objectives could potentially conflict with each other, and that the divide could turn out to be difficult to bridge. This gives little indication as to where future practices may be heading. However, despite the obvious trend to enhanced convergence in regulatory approaches, which is certainly fuelled also by the integration of different national perspectives in the day-to-day organisation of supervision within the ECB, a further individualisation rather than the streamlining of governance requirements is to be, and perhaps should be, expected in particular to more general, non-technical areas of bank organisation. Over time, this could lead to supervisory policies that will be tailored to the needs of each particular institution or group. These policies would then be informed by the ECB's comparative expertise and thus indeed reflect a growing body of "best practice", but in an adaptive, flexible way. As discussed above, the most likely field for the development of technical best practice could turn out to be the evolution of internal strategies and processes under the ICAAP and internal modeling regimes. Whether, and to what extent, the emergence of such standards will also lead to interference with specific commercial decisions, e.g., with respect to investments in sovereign debt issued by the Member State in which the relevant institution is located, remains to be seen, but early signs indicate that the ECB is also prepared to take a bold stance in this regard. ${ }^{125}$

At any rate, just as the governance-related provisions of the CRD IV package are designed as facilitating a gradual, evolutionary refinement over time, the development of the ECB's supervisory policies and strategies is likely to emerge not overnight, but organically over the coming months and years, on the basis of an ever growing body of expertise gained throughout the day-to-day monitoring of supervised institutions.. In this regard, the "Joint Superviso-

\footnotetext{
${ }^{124}$ See, again, ECB, Guide, supra n. 32, para. 7.

${ }^{125}$ See, noting an ECB decision to prohibit Greek lenders to purchase further sovereign debt issued by Greece, e.g., "ECB to tighten noose on Greek government", EU Observer, 25 March 2015, available at https://euobserver.com/news/128139. The ECB has made it known that existing supervisory practices will be reviewed and, possibly, adjusted over time, see Letter of the Chair of the Supervisory Board, Danièle Nouy, to the management of significant banks dated 27 January 2015. It has also adopted a formal recommendation on dividend distribution policies, which, although not strictly within the focus of the present paper, clearly indicates the willingness to interfere with received practicies, see Recommendation ECB/2015/2 of 29 January 2014. Both documents are available at https://www.bankingsupervision.europa.eu/banking/letterstobanks/html/index.en.html.
} 
ry Teams" of ECB and NCA staff, through which the ECB will perform its supervisory tasks, ${ }^{126}$ are likely to play a decisive role in the relevant accumulation of such expertise. ${ }^{127}$ The Banking Union's implications on the governance of credit institutions are, in other words, difficult, if not impossible, to predict: We are likely to see them emerge gradually - and this will take time. The findings developed in the present paper suggest that, in addition to the removal of impediments to resolvability in the sense discussed above, internal control arrangements should play a major role in this respect.

${ }^{126}$ See SSM Framework Regulation, supra n. 17, Arts. 3-6.

${ }^{127}$ Cf., indicating a similar position, ECB, Guide, supra n. 32, at paras 21-3: "The process for the supervision of credit institutions can be envisaged as a cycle (...): regulation and supervisory policies provide the foundation for supervisory activities and for the development of supervisory methodologies and standards. The methodologies and standards underpin the day-to-day supervision that is carried out to the same high standards across all credit institutions. Through various channels, including the SSM's participation in international and European fora, the lessons learnt in the course of supervision and the performance of quality assurance checks feed back into the definition of methodologies, standards, supervisory policies and regulation. Experience gained from the practical implementation of the methodologies and standards feeds through to the planning of supervisory activities for the forthcoming cycle. This planning also incorporates the analysis of key risks and vulnerabilities and strategic supervisory priorities." 


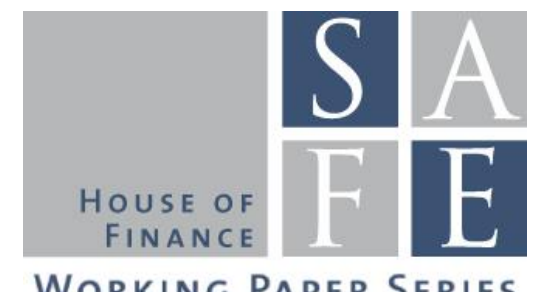

WORKING PAPER SERIES

\section{Recent Issues}

No. 95 Loriana Pelizzon, Marti G.

Subrahmanyam, Davide Tomio, Jun Uno

No. 94 Claudia Lambert, Felix Noth, Ulrich Schüwer

No. 93 Shafik Hebous, Tom Zimmermann

No. 92 Christoph Hambel, Holger Kraft, Eduardo S. Schwartz

No.91 Anne-Caroline Hüser

No.90 Pinar Topal

No. 89 Julia Braun, Alfons J. Weichenrieder

No. 88 Ester Faia, Beatrice Weder di Mauro

No. 87 Iñaki Aldasoro, Domenico Delli Gatti, Ester Faia

No. 86 Agar Brugiavini, Danilo Cavapozzi, Mario Padula, Yuri Pettinicchi

No. 85 Holger Kraft, Claus Munk, Sebastian Wagner

No. 84 Raimond Maurer, Olivia S. Mitchell, Ralph Rogalla, Tatjana Schimetschek

No. 83 Patrick Grüning

No. 82 Edgar Vogel, Alexander Ludwig, Axel Börsch-Supan
Sovereign Credit Risk, Liquidity, and ECB Intervention: Deus Ex Machina?

How Do Banks React to Catastrophic Events? Evidence from Hurricane Katrina

Revisiting the Narrative Approach of Estimating Tax Multipliers

Optimal Carbon Abatement in a Stochastic Equilibrium Model with Climate Change

Too Interconnected to Fail: A Survey of the Interbank Networks Literature

Fiscal Stimulus and Labor Market Flexibility

Does Exchange of Information between Tax Authorities Influence Multinationals' Use of Tax Havens?

Cross-Border Resolution of Global Banks

Bank Networks: Contagion, Systemic Risk and Prudential Policy

Financial education, literacy and investment attitudes

Housing Habits and Their Implications for LifeCycle Consumption and Investment

Will They Take the Money and Work? An Empirical Analysis of People's Willingness to Delay Claiming Social Security Benefits for a Lump Sum

International Endogenous Growth, Macro Anomalies, and Asset Prices

Aging and Pension Reform: Extending the Retirement Age and Human Capital Formation 